Path. Microbiol. 1973;39:I-VI

\title{
Contents, Vol. 39, 1973
}

\section{Vol. 39, 1973}

Pathologia et Microbiologia

Founded 1938 by A. v. Albertini, A. Grumbach and H. Mooser

Offizielles Organ der Schweiz. Mikrobiologischen Gesellschaft

Organe officiel de la Société Suisse de Microbiologie

Official Organ of the International Society of Geographical Pathology

Editors: $\quad$ H. Ramseier, Zurich

J. R. Rüttner, ZurichmiS. Karger · Basel $\cdot$ München $\cdot$ Paris $\cdot$ London $\cdot$ New York $\cdot$ Sydney

Index

Pitton, J. S. (Geneve): /?-Lactamase à dépendance plasmidique chez les entéro-

bactériacées

3

Wüst, J. und Kayser, F. H. (Zurich): Transduktion der Methicillinresistenz bei

Staphylococcus aureus

4

Huber, B. und Kayser, F. H. (Zurich): Staphylococcus epidermidis als Infek-

tionserreger 6

Ribeiro, O.; Demierre, G. et Bonifas, V. (Lausanne): Etudes longitudinales

des staphylocoques isolés de malades hospitalises

8

Goetz, M.L.; Reeb, E. et Lavillaureix, J. (Strasbourg): Contribution à Гétude

biologique du staphylocoque, dans le cadre d'une enquête perma-

nente d'hygiène hospitalière au CHU de Strasbourg 10

Beer, K. (Lugano): Milzbrandmeningitis

12

Weissmann, C. (Zurich): RNA-haltige Viren als Tumorerreger 14

Ivaniф, S. (Zurich): Nonspecific Inhibitors of Arbovirus Hemagglutinin

Bächi, Th. (Zurich): Ultrastrukturelle Untersuchungen über die Fusion von

Menschenerythrozyten mit Sendai-Viren

19

Gasser, M.; Sulzberger, B. und Erb, P. (Basel): Der Einfluss der Antigendosis

auf die Anzahl Plaque-bildender Zellen in jungen Hamstern 20

Fey, H. (Bern): Eriochromschwarz, ein Mittel zur Reduktion der Unspezifität bei der Immunofluoreszenz 22

Hirt, B. (Lausanne): Werden Tumoren durch DNA-Viren erzeugt? 24

Cuendet, Jacqueline et Bonifas, V. (Lausanne): Mode (nouveau) d'envelop-

pement d'un Herpesvirus 32

Wandeler, A.; Kunz, Ch. und Steck, F. (Bern): Beobaditungen über die zentraleuropäische Zeckenenzephalitis in der Schweiz 35

Polak, Annemarie and Grenson, Marcelle (Basel/Bruxelles): Interference between the Uptake of Pyrimidines and Purines in Yeasts 37

Liersch, M.; Nüesch, J. und Treichler, H. J. (Basel): Methioninstoffwechsel

und Cephalosporin-C-Synthese in Cephalosporium acremonium 39

Landolt-Sydler, Maryvonne; Schürch-Rathgeb, Yvonne und Hütter, R. 
(Zurich): Organisation des Tryptophan-2- und des Tryptophan-3-Gens

in Saccharomyces cerevisiae 40

Miozzari, J.; Schürch, A. und Hütter, R. (Zurich): Zur Regulation der Tryp-

tophan-Biosynthese bei Saccharomyces cerevisiae 42

Lüthy, P.; Scherrer, P. und Trümpi, B. (Zurich): Zur Bildung und Wirkung

des Endotoxins von Bacillus thuringiensis 44

Index Io

Rassekh, M. et Pitton, J. R. (Geneve): Caractérisation des mécanismes de

resistance à la streptomycine chez les entérobactériacées $\quad 45$

Mavrothalassitis, P.; Demierre, G. et Ribeiro, O. (Lausanne): Comparaison

des milieux standard pour Гisolement des Salmonella et Shigella

avec un milieu non sélectif à propriétés tinctoriales 47

Desbresles, A. M. B. (Lyon): A propos de Tutilisation d'une microméthode

d'identification des entérobactéries 49

Schneider, P. A. (Lausanne): Reaction de precipitation dans le diagnostic des

Yersinia $\quad 50$

Knapp, W. (Erlangen): Zur Bakteriologie und Serologie von Yersinia entero-

colitica (Syn. Pasteurella X) 51

Wuhrmann, K. (Dübendorf): Bedeutung der Mikroorganismen für aquatische

Stofikreisläufe 55

Engelbrecht, E. (Geneve): Le «Bioreactor». Automatic polyvalent pour le laboratoire d'analyse 71

Piguet, J. D. (Geneve): Emploi d'un ordinateur pour la gestion d'un labora

toire de microbiologie médicale $\quad 76$

Rossier, E. and Bourgaux-Ramoisy, Danielle (Sherbrooke, Que.): A New

Tissue-Culture System for Clinical Virology 81

Gilani, S. H. (Newark, N.J.): Congenital Cardiac Anomalies in Lead

Poisoning 85

Segal, E. and Eylan, E. (Ramat-Aviv): Antigenic Relationship between the

Fission-Yeast Schizosaccharomyces pombe, Ascosporogenous and

Asporogenous Yeasts 91

Brantner, H. und Fischer, G. (Graz): Untersuchungen der Kininasen des on-kolytisch wirksamen

Clostridium-Stammes M 55 ATCC13732 mittels Chelatbildner

(Examination of the Kininasen in an Oncolytic Clostridium [Strain

M 55 ATCC 13732] by means of Chelate-Forming Agents) 99

Ban $1 / 8$, S. and Budiö, Sonja (Ljubljana): Study of the Efficiency of some Modi

fications of Medium B-2 for the Primary Cultivation of Tubercle

Bacteria $\quad 107$

Valdivia, E. and Berger, J. E. (Madison, Wise/Buffalo, NY.): Atypical Elec

tron Microscope Structures in Liver Mitochondria 112

Dinges, H. P.; Kovac, W.; Hofmann, H. und Kunz, Ch. (Wien): Die Marburg-

Virus-Enzephalitis der weissen Maus

(Vervet Monkey Disease in Mice) 115

Kyriakidou, A.; Kourea-Kremastinou, T.; Papaevangelou, G., and Vassi-

liadis, P. (Athens): Detection of Vaccinia Antigen and Antibody by

Counterelectrophoresis $\quad 126$ 
Muszyñski, Z. (Poznań): Enzymatic and Toxinogenic Activity of Culture Fil trates of High and Low Virulent Strains of Pseudomonas aeruginosa on Mice $\quad 135$

Polak, Annemarie and Scholer, H. J. (Basle): Fungistatic Activity, Uptake and Incorporation of 5-Fluorocytosine in Candida albicans, as In fluenced by Pyrimidines and Purines. I. Reversal Experiments 148 Hutt, M. S. R. (London): Nature's Experiments and Medical Research

IV

\section{Index}

Burkitt, D. P. (London): Disease of the Alimentary Tract and Western Diets 177 Cameron, H. M. (Nairobi): Oral Tumours in Kenya 187

Adatia, A. K. (Bristol): Dental Changes in Burkitt's Lymphoma 196

Prætorius-Clausen, F. (Copenhagen): Geographical Aspects of Oral Focal Epithelial Hyperplasia 204

Brocheriou, C; Chomette, G.; Cernea, P.; Auriol, M. et Helenon, R.

(Paris): Cancer in situ et micro-invasif de la cavité buccale. Etude

morphologique et statistique 214

Baker, S. J. (Vellore): Geographical Variations in the Morphology of the Small Intestinal Mucosa in Apparently Healthy Individuals 222

Neale, G. (London): The Geographical Incidence of Lactase Deficiency

Dutz, W.; Azadeh, B.; Kohout, Elfriede, and Vessal, Karim (Shiraz): In

fantile Enteritis as a Cause of Thymolymphatic Atrophy 248

Williams, R. E. O. (London): Geographical Differences in the Bacterial Flora of the Gut 249

Wright, N. A.; Morley, A. R.; Appleton, D. R.; Marks, J. M.; Douglas, A. P., and Watson, A. J. (Newcastle upon Tyne): Measurement of Cell Production Rate in the Human Small Bowel 251

Kurland, L. T. (Rochester, Minn.): Incidence and Long-Term Trends of Disease in Rochester, Minn. Methodology and Results with Special Emphasis on Cancer of the Bowel and Ulcerative Colitis 254 Cook, G. C. (Lusaka): Some Observations on Carbohydrate and Amino Acid Absorption in Zambian African Subjects in Relation to Systemic Bacterial Infections 256

Kearney, M. S. (Liverpool): Ultrastmctural Changes in the Heart at High Altitude 258

Heath, D. (Liverpool): The Histological Features and Physical Characteristics of the Pulmonary Trunk at High Altitude 266

Kay, J. M. and Smith, P. (Liverpool): The Small Pulmonary Arteries in Rats at Simulated High Altitude 270

Wagenvoort, C. A. and Wagenvoort, N. (Amsterdam): Hypoxic Pulmonary

Vascular Lesions in Man at High Altitude and in Patients with

Chronic Respiratory Disease 276

Arias-Stella, J.; Krüger, H., and Recavarren, S. (Lima): On the Pathology

of Chronic Mountain Sickness 283

Becker, A. E. (Amsterdam): Normal Structure, Ultrastructure and Enzyme Content of Glomic Cells 287 
Arias-Stella, J. and Valcarcel, J. (Lima): The Human Carotid Body at High Altitudes 292

Edwards, C. W. (Birmingham): The Carotid Bodies in Animals at High Alti

tude 298

Heath, D. (Liverpool): The Carotid Body in Human Cardiopulmonary Disease 305

Blessing, M. H. and Wolff, H. (Düsseldorf): The Carotid Bodies at Simulated

High Altitude 310

Kistler, G. S.; Sonnabend, W., and Krech, U. (St. Gallen): Hepatitis B An

tigen (HB-Ag, Australia Antigen) in Mixed Saliva of Patients with

HB Antigenemia 313

Index $\mathrm{V}$

IvaniEová, S. (Zurich): Electrophoretic Studies on Influenza A2 Virus and its

Components 319

Polak, Annemarie and Scholer, H. J. (Basel): Fungistatic Activity, Uptake

and Incorporation of 5-Fluorocytosine in Candida albicans, as In

fluenced by Pyrimidines and Purines. II. Studies on Distribution and

Incorporation 334

Schmid, E. und Sonnabend, W. (St. Gallen): Über das Vorkommen entero-

pathogener Serotypen von Escherichia coli bei Harnwegsinfektionen

(On the Occurrence of Enteropathogenic Serotypes of Escherichia

coli in Urinary Tract Infections) 348

Stünzi, H. (Zurich): Zur vergleichenden Pathologie des Lungenkarzinoms beim Haustier

(Comperative Pathology in Pulmonary Carcinoma in Domestic

Animals) $\quad 358$

Müller, H. E. und Marklein, G. (Bonn): Untersuchungen zur proteolytischen

Enzymaktivität bei Bacillus anthracis und Bacillus cereus

(Studies on the Activity of Proteolytic Enzymes in Bacillus anthracis

and Bacillus cereus) 364

Bruch, J. and Sethi, K. K. (Bonn): Electron Microscopy of Ultrathin Sections

of Mycoplasma gallisepticum (Strain TT) Organisms Grown on

Glass Surface 373

Reuber, M. D. and Glover, E. L. (Baltimore, Md.): Chronic Thyroiditis in

Buffalo-Strain Rats Ingesting 3'-Methyl-4-Dimethylaminoazobenzene

of N-2-Fluorenyldiacetamide 383

Wilkie, B.; Pauli, B., and Gygax, M. (Bern): Hypersensitivity Pneumonitis:

Experimental Production in Guinea Pigs with Antigens of Micro-

polyspora faení 393

Ariel, B. M.; Khavkin, T. N., and Amosenkova, N. I. (Leningrad): Interaction between Coxiellae burnetii and the Cells in Experimental Q-Rickett-

siosis. Histologic and Electron Microscope Studies 412

Singh, D. S. and Pavgi, M. S. (Varanasi): Conidial Release in Pyricularia pen-

niseti 424

Rohde, R. und Pagon, S. (Hamburg/St. Gallen): Isolierung eines neuen Salmonella- (S.

II41:b:1,5) sowie Arizona-Serotypes (Arizona 21:24:25) aus einer Kettenviper (Vipera russellii) 
(A new Salmonella Serotype [S. II 41:b:1,5] and a new Arizona Serotype [Arizona 21:24:25] were isolated from a Snake Vipera rus sellii) 429

Wysor, M. S. and Zollinhofer, R. E. (Ithaca, N.Y.): Deoxyribonucleic Acid Repair Replication in Pseudomonas aeruginosa after Sublethal Doses of Silver Sulfadiazine 434

Rubin, D. and Levij, I. S. (Jerusalem): Suppression by Vitamins D2 and D3 of Hamster Cheek Pouch Carcinoma Induced with 9,10-Dimethyl-1,2benzanthracene. With a Discussion of the Role of Intracellular Cal cium in the Development of Tumors 446

Budillon, G.; Carrella, M.; De Marco, F., and Mazzacca, G. (Naples): Effect of Phenobarbital on MHV-3 Viral Hepatitis of the Mouse 461 VI

Index

Proceedings $\cdot$ Verhandlungsberichte . Congrès

Schweizerische Mikrobiologische Gesellschaft, 31. Jahresversammlung, 8. bis 10. Juni 1972 in Einsiedeln - Société Suisse de Microbiologie, 31e assemblée annuelle, les 8 au 10 juin 1972 à Einsiedeln 1 Oral Pathology $\cdot$ Intestinal Pathology $\cdot$ Hypobaric Pathology Proceedings of the 11 th Conference of the International Society of Geographical

Pathology, Newcastle upon Tyne, August 17-22, $1972 \quad 167$

Book Reviews · Buchbesprechungen · Livres Nouveaux $\quad 79,160,389,467,468$

Errata 160

Varia 80

Subject Index 469

Authors' Index 